\title{
Wet impregnation of silver oxide on Lampung natural zeolite as an adsorbent to produce oxygen-enriched air using PSA technique
}

\author{
Adenia Gita Dianty, Andrea Rizky Sabrina Harahap, Claudia Harfian, Setijo Bismo* \\ Chemical Engineering Department, Universitas Indonesia, Kampus Baru UI Depok, Depok 16424, Indonesia
}

\begin{abstract}
High purity oxygen can be used for various things. Oxygen purification method to be applied on this research is the Pressure Swing Adsorption (PSA) technique. The adsorbent that would be used is a natural zeolite, namely ZAL (Zeolite Alam Lampung). Natural zeolite has non-polar properties, so it will adsorb gas with high quadruple moment, which is nitrogen. The varied variable is the size of adsorbent and the concentration of $\mathrm{H}_{2} \mathrm{SO}_{4}$. The sizes are 18-35 mesh, 35-60 mesh, and 60-100 mesh. While the $\mathrm{H}_{2} \mathrm{SO}_{4}$ concentration are $1 \mathrm{M}, 2 \mathrm{M}$ and $3 \mathrm{M}$. Size of $\mathrm{ZAL}$, and the concentration of sulfuric acid $\left(\mathrm{H}_{2} \mathrm{SO}_{4}\right)$ were varied to get the optimum value. The adsorbent will be activated in aqua demine, $\mathrm{H}_{2} \mathrm{SO}_{4}, \mathrm{NaOH}$, and through a calcination process. The purpose of this pre-treatment was to remove the impurities and to increase the specific surface area of zeolite. Moreover, ZAL will also be modified by wet impregnation technique using $\mathrm{AgNO}_{3}$ solution with $1 \%$-wt loading nominal. The morphology, composition, and crystal phase were characterized by BET, scanning electron microscopy with energy dispersive X-ray spectroscopy (SEMEDX). The result of the adsorption process was analyzed by using GC (Gas Chromatograph). ZAL 35-60 mesh $1 \mathrm{M}$ showed the best performance on adsorbing nitrogen, with its lowest peak at $60356 \mu \mathrm{V}$. The result of this research suggested that ZAL itself has the main role on adsorbing nitrogen, while $\mathrm{Ag}_{\mathrm{x}} \mathrm{O}$ did not give any significant effect
\end{abstract}

\section{Introduction}

Oxygen is a vital chemical element that has an important role, either for a human metabolic system as well as for other purposes. The utilization of oxygen will increase for high purity oxygen. High purity oxygen can naturally be used widely, such as in chemical processes, medical applications, combustion processes, bleaching in the paper industry, wastewater treatment, fuel cells, and also to produce ozone. Oxygen can be obtained from air. However, air contains a variety of gases which is, oxygen, nitrogen, argon, and others. In this study, the process of purification of oxygen from air using PSA (Pressure Swing Adsorption) technique will be examined. PSA technique produced high purity molecules with relatively low cost. The adsorption process that applies on PSA technique is based on the pressure different, in which the gas molecules will be bound to the adsorbent. The use of PSA to separate oxygen from air was designed so that the nitrogen is adsorbed, while oxygen passes. The process of separating oxygen from the air PSA techniques will rely on the use of mineral aluminosilicate, known as zeolite to be a selective adsorbent of nitrogen [6].

Zeolite is a mineral that has a very unique crystal structure. Zeolite have a wide range of uses, as catalysts, ion exchangers and as absorbers of organic compounds. Natural zeolite as an adsorbent capable of capturing nitrogen to enrich oxygen content in air. Therefore, this study will focus on the preparation of natural zeolite as well as its activation especially ZAL (Natural Zeolite containing Clinoptilolite as major substituent, from Sidomulyo, Lampung-Indonesia) as an adsorbent. The unique crystal structure of the zeolite allows for the modification of zeolites as needed. Natural zeolite from Lampung, Indonesia has wide surface area and good thermal stability, and it is abundant [7]. ZAL will be modified with silver oxide $\left(\operatorname{Ag}_{x} \mathrm{O}\right)$ to improve the properties of ZAL as an adsorbent so that it will increase adsorption and produce high-purity oxygen [8]. The modification method that used is wet impregnation. Wet impregnation is a preparation technique with the objection to filled $\mathrm{ZAL}$ pores with $\mathrm{Ag}_{\mathrm{x}} \mathrm{O}$ to broaden the adsorption surface area of ZAL, by soaking the ZAL with aqueous solution of $\mathrm{AgNO}_{3}$ [3].

\section{Methodology and Results}

\subsection{Methodology/Experimental}

Three sizes of ZAL was used, which was the $18-35$ mesh, $35-60$ mesh, and $60-100$ mesh. Beforehand, the ZAL sizes were uniformed by milling and shaker. First, the ZAL was washed thoroughly with aqua demine water, then dried in oven at $110^{\circ} \mathrm{C}$ for 2 hours. Second, the ZAL was pre-treated with $1 \mathrm{~mole} / \mathrm{L}, 2 \mathrm{~mole} / \mathrm{L}$ and $3 \mathrm{~mole} / \mathrm{L}$ of $\mathrm{H}_{2} \mathrm{SO}_{4}$ and $1 \mathrm{~mole} / \mathrm{L} \mathrm{NaOH}$ for respectively an hour to remove impurities, enlarge pore volume and surface area

\footnotetext{
* Corresponding author: sbismo@che.ui.ac.id
} 
of ZAL [2]. Before the impregnated process, ZAL were washed again with aqua demine water until the $\mathrm{pH}$ was neutral, then dried in the oven for 2 hours at $110^{\circ} \mathrm{C}$. Then, the treated ZAL was impregnated in aqueous solution of $\mathrm{AgNO}_{3}$ in an agitator for 12 hours with the loading percentage of $1 \%$-wt. Lastly, $\mathrm{Ag}_{\mathrm{x}} \mathrm{O} / \mathrm{ZAL}$ go through a calcination process at $350^{\circ} \mathrm{C}$ for 1.5 hours to release the $\mathrm{NO}_{2}$.

Specific surface area and pore volume was determined by BET method using nitrogen adsorption at the boiling temperature of liquid nitrogen. ASAP 2020 by Micromeritics was used for BET instrument. Before measurements, samples were degassed at $300^{\circ} \mathrm{C}$. Surface morphology of $\mathrm{Ag}_{\mathrm{x}} \mathrm{O} / \mathrm{ZAL}$ were observed by scanning electron microscopy (SEM) and surface composition analysis was carried out by energy dispersive X-ray spectroscopy (EDX). The magnitude for SEM was x 5,000 and the voltage was $20 \mathrm{kV}$. The accelerating voltage for EDX was $20 \mathrm{kV}$ and the energy range for EDX was between $0-20 \mathrm{keV}$.

The adsorption activity test of ZAL was investigated using PSA technique, on a packed bed reactor (PBR) made out of stainless steel. Air from the environment was compressed with a compressor through a heater with the temperature of $75^{\circ} \mathrm{C}-95^{\circ} \mathrm{C}$, after that the air went through a silica gel bed to remove its water content. Then, the PSA process occur for about 30 minutes with the pressure of 4 bar. The gas sample was taken at every 5 minutes for each running process, in which it was then analyzed by Gas Chromatography (GC) to know the composition and the intensity of every component that was contained within.

\subsection{Results and Discussions}

The BET characterization was done to three ZAL samples that has the best result after GC analysis, which was ZAL 35 - 60 mesh 1 mole/L, ZAL 60 - 100 mesh 1 mole/L, and ZAL $60-100$ mesh 2 mole/L. The purpose of the BET characterization was to identify the pore volume, so the amount of solid $\mathrm{AgNO}_{3}$ that needed to be used can be known to obtain the $1 \%$-wt impregnation. The Table 1 below, shows the result of BET characterization and the difference of pores volume and specific surface area before and after the pre-treatment process for the $60-100$ mesh ZAL. As we can see on the Table 1 below, the pore diameter, surface area and pore volume of each ZAL increased. The increase was caused by the removal of impurities within ZAL pores because of the activation by aqua demine, sulfuric acid, and also natrium hydroxide. The increase on pore diameter, pore volume and surface area will also increase ZAL capability on adsorbing nitrogen and produce oxygen enriched-air.
Table 1. BET Characterization of ZAL

\begin{tabular}{cccccc}
\hline \multirow{2}{*}{ Paramet-er } & $\begin{array}{c}\text { ZAL 35- } \\
60 \mathrm{mesh} \\
1 \mathrm{~mole} / \mathrm{L}\end{array}$ & \multicolumn{2}{c}{$\begin{array}{c}\text { ZAL 60-100 mesh } \\
1 \text { mole/L }\end{array}$} & \multicolumn{2}{c}{$\begin{array}{c}\text { ZAL 60-100 mesh } \\
2 \text { mole/L }\end{array}$} \\
\cline { 2 - 6 } & After & Before & After & Before & After \\
\hline $\begin{array}{c}\text { Pore } \\
\text { diameter } \\
(\mathrm{nm})\end{array}$ & 11.047 & 9.105 & 11.000 & 9.105 & 11.138 \\
$\begin{array}{c}\text { Surface } \\
\text { area } \\
\left(\mathrm{m}^{2} / \mathrm{g}\right) \\
\begin{array}{c}\text { Pore } \\
\text { volume } \\
\left(\mathrm{cm}^{3} / \mathrm{g}\right)\end{array}\end{array}$ & 0.117 & 0.091 & 0.099 & 0.091 & 0.127 \\
\hline
\end{tabular}

The impregnation was done to the three selected ZAL in agitator for 12 hours with a respectable amount of $\mathrm{AgNO}_{3}$ used. The wet impregnation turned ZAL color from pure white into golden yellow [4]. The color change in zeolite after the impregnation process can be seen on the Table 2 below. This was caused by the formation of silver clusters within ZAL pores and surfaces [5]. The amount of $\mathrm{Ag}_{\mathrm{x}} \mathrm{O}$ that impregnated within the zeolite pores and surface correspond to the color change. The more AgxO amount that got impregnated, will caused the zeolite to turn into dark yellow [4]. Based on Table 2, we can see that $\mathrm{Ag}_{\mathrm{x}} \mathrm{O} / \mathrm{ZAL} 60-100$ mesh 1 mole/L has the darkest color of all, then it followed by $\mathrm{Ag}_{\mathrm{x}} \mathrm{O} / \mathrm{ZAL} 35-$ 60 mesh 1 mole/L, and after that $\mathrm{Ag}_{\mathrm{x}} \mathrm{O} / \mathrm{ZAL} 60-100$ mesh 2 mole/L. A calcination was done to remove water molecules, impurities, and to form a bond between the silver oxide and ZAL. Then, to know the success of the impregnation process, EDX, and XRF characterization will be done to know the detailed composition of the ZAL samples.

Table 2. Color Changes of ZAL after Impregnation

\begin{tabular}{cccc}
\hline ZAL & $\begin{array}{c}\text { ZAL 35-60 } \\
\text { mesh 1 } \\
\text { mole/L }\end{array}$ & $\begin{array}{c}\text { ZAL 60-100 } \\
\text { mesh 1 }\end{array}$ & ZAL 60-100 \\
& mole/L & mole/L \\
\hline $\begin{array}{c}\text { Before } \\
\text { Impregnation }\end{array}$ & & & \\
After & & & \\
Impregnation & & & \\
& & & \\
\hline
\end{tabular}


Table 3. EDX characterization of $\mathrm{AgO} / \mathrm{ZAL}$

\begin{tabular}{|c|c|c|c|}
\hline \multirow[b]{3}{*}{ Composition } & \multicolumn{3}{|c|}{$\%$-atom } \\
\hline & \multicolumn{3}{|c|}{ After Impregnation } \\
\hline & $\begin{array}{c}35-60 \\
\text { mesh } \\
1 \mathrm{~mole} / \mathrm{L}\end{array}$ & $\begin{array}{c}60-100 \\
\text { mesh } \\
1 \text { mole/L }\end{array}$ & $\begin{array}{c}60-100 \text { mesh } \\
2 \text { mole/L }\end{array}$ \\
\hline $\mathrm{O}$ & 56.57 & 61.85 & 42.82 \\
\hline $\mathrm{Na}$ & 1.60 & 1.37 & 1.31 \\
\hline $\mathrm{Al}$ & 5.38 & 5.64 & 6.50 \\
\hline $\mathrm{Si}$ & 34.90 & 29.83 & 45.33 \\
\hline K & 1.22 & 1.01 & 2.07 \\
\hline $\mathrm{Fe}$ & - & - & 1.50 \\
\hline $\mathrm{Ag}$ & 0.33 & 0.30 & 0.47 \\
\hline \multirow[b]{3}{*}{ Composition } & \multicolumn{3}{|c|}{$\%$-atom } \\
\hline & \multicolumn{3}{|c|}{ After Impregnation } \\
\hline & $\begin{array}{c}35-60 \\
\text { mesh } \\
1 \mathrm{~mole} / \mathrm{L}\end{array}$ & $\begin{array}{c}60-100 \\
\text { mesh } \\
1 \mathrm{~mole} / \mathrm{L}\end{array}$ & $\begin{array}{c}60-100 \text { mesh } \\
2 \text { mole/L }\end{array}$ \\
\hline $\mathrm{O}$ & 56.57 & 61.85 & 42.82 \\
\hline $\mathrm{Na}$ & 1.60 & 1.37 & 1.31 \\
\hline $\mathrm{Al}$ & 5.38 & 5.64 & 6.50 \\
\hline $\mathrm{Si}$ & 34.90 & 29.83 & 45.33 \\
\hline $\mathrm{K}$ & 1.22 & 1.01 & 2.07 \\
\hline $\mathrm{Fe}$ & - & - & 1.50 \\
\hline $\mathrm{Ag}$ & 0.33 & 0.30 & 0.47 \\
\hline
\end{tabular}

Surface morphology and composition of ZAL for before and after impregnation process. As seen on both Table 3 and Table 5, there were many impurities in the surface area of ZAL before impregnation and calcination. Based on the analysis and characterization of ZAL before and after impregnation, it showed that the ratio for $\mathrm{Si} / \mathrm{Al}$ was increased. Siloxane is an organosilicon compound which has Si-O-Si chain. Si-O itself is a destructed framework from acid cleaning phase [1]. The increased ratio of $\mathrm{Si} / \mathrm{Al}$ was caused by dealumination process, that made the ZAL became hydrophobic, more stable under high temperature and high acid environment and can adsorb non-polar molecules. $\mathrm{Ag}_{\mathrm{x}} \mathrm{O} / \mathrm{ZAL}$ will have a high selectivity to nitrogen because nitrogen is a non-polar molecule that has high dipole moment. As we can see on Table 5, by comparing ZAL images from SEM characterization, we can see that the zeolite crystals look clearer and more define. This due to the calcination process after impregnation, that makes all of the impurities that were trapped inside the zeolite pores removed.

Table 4. $\mathrm{Si} / \mathrm{Al}$ of ZAL samples

\begin{tabular}{clcc}
\hline \multicolumn{2}{c}{ Sample } & Si/Al Ratio & \%Change \\
\hline $35-60 \mathrm{mesh}$ & Activated & 6.584 & \\
$1 \mathrm{~mole} / \mathrm{L}$ & Impregnated & 6.486 & 1.494 \\
$60-100 \mathrm{mesh}$ & Activated & 6.111 & \\
$1 \mathrm{~mole} / \mathrm{L}$ & Impregnated & 5.286 & 13.491 \\
$60-100 \mathrm{mesh}$ & Activated & 6.086 & \\
$2 \mathrm{~mole} / \mathrm{L}$ & Impregnated & 6.973 & 14.567 \\
\hline
\end{tabular}

Table 5. SEM characterization of ZAL samples

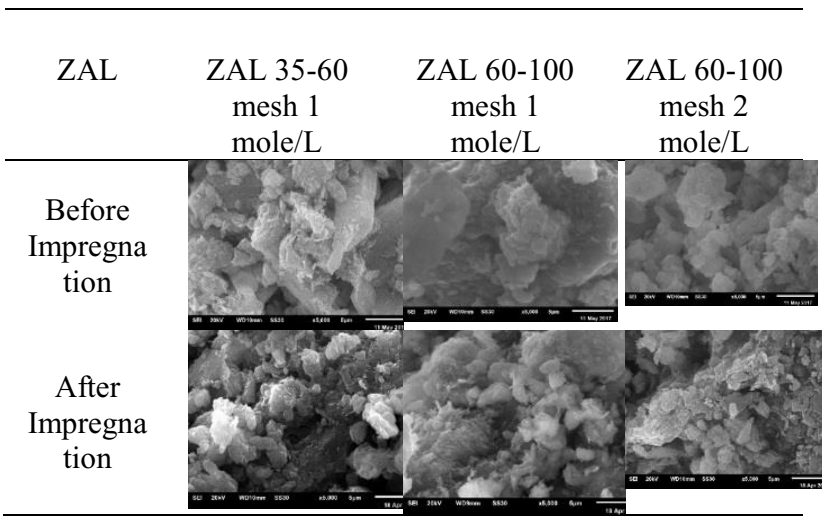

Table 6 showed the loading percentage of $\mathrm{Ag}_{\mathrm{x}} \mathrm{O}$ for three samples of ZAL after the impregnation process. The values are only reaching half of the designated values, which is only $0.5 \%$-wt $\operatorname{Ag}_{\mathrm{x}} \mathrm{O}$. This may be happened because not all of the Ag latch through the ZAL pores and surfaces. While the $\mathrm{Si} / \mathrm{Al}$ ratio showed that the impregnated 35-60 mesh 1 mole/L ZAL has the highest value, and this is quite a different result from the EDX characterization one. The XRF characterization take measurement from 5 grams of ZAL, and average it, while EDX characterization only take measurement from only a small portion of ZAL sample. So it is more accurate to look at XRF result of characterization. The high ratio of $\mathrm{Si} / \mathrm{Al}$ will make ZAL become more responsive to nitrogen and help the adsorption process become better. Based on the XRF characterization as seen on table 6, the impregnated ZAL sample that have the highest $\mathrm{Si} / \mathrm{Al}$ ratio is the $35-60$ mesh 1 mole/L. This impregnated ZAL samples will have a better absorbency level rather than the other two samples. The GC analysis result will be show on Figure 2, and will be explain afterwards. The ZAL sample that has the highest amount of $\mathrm{Ag}_{\mathrm{x}} \mathrm{O}$ impregnated is the $60-100$ mesh $1 \mathrm{~mole} / \mathrm{L}$ sample, this support the statements that the more $\mathrm{Ag}_{\mathrm{x}} \mathrm{O}$ impregnated in the zeolite pores or surface will make the color of the zeolite become darker.

Table 6. XRF characterization of ZAL samples

\begin{tabular}{lccc}
\hline \multicolumn{4}{c}{ Parameter } \\
\hline Element & $\begin{array}{c}35-60 \\
\text { mesh } \\
1 \mathrm{~mole} / \mathrm{L}\end{array}$ & $\begin{array}{c}60-100 \\
\text { mesh } \\
1 \mathrm{~mole} / \mathrm{L}\end{array}$ & $\begin{array}{c}60-100 \\
\text { mesh } \\
2 \mathrm{~mole} / \mathrm{L}\end{array}$ \\
\hline $\begin{array}{l}\mathrm{Ag} \mathrm{( \% -} \\
\text { weight) }\end{array}$ & 0.25 & 0.39 & 0.30 \\
$\begin{array}{l}\mathrm{Si}(\%- \\
\text { weight) }\end{array}$ & $83.7 \pm 0.3$ & $80.7 \pm 0.4$ & $81.3 \pm 0.1$ \\
$\begin{array}{l}\mathrm{Al}(\%- \\
\text { weight) }\end{array}$ & $10.2 \pm 0.3$ & $10.6 \pm 0.4$ & $10.2 \pm 0.5$ \\
$\mathrm{Si} /$ Al Ratio & 8.20 & 7.61 & 7.97 \\
\hline
\end{tabular}

The Figure 1 showed the graph that correlating the time of taking the sample versus the peak height that represents the intensity of nitrogen component analyzed in the GC. The ZAL that were used to adsorbed nitrogen were the 35- 60 mesh 1 mole/L, ZAL 60 - 100 mesh 1 mole/L, and $60-100$ mesh 2 mole/L. ZAL that had been pre-treated had the capability to adsorb nitrogen, which 
shown on the graph that for some sample the peak height has a slight decreased. The reason on why the graph tends to decreased to a low point and increased again was because the ZAL was already saturated with nitrogen molecules, in which the adsorption rate became lower. As shown on the Figure 2, the best ZAL adsorbent that has high stability of adsorbing nitrogen was the $60-100$ mesh 2 mole/L [4]. While the others still tend to fluctuates slightly. But, ZAL $35-60$ mesh 1 mole/L has the lowest peak number that correlates that the adsorbent has the best capability to adsorb nitrogen.

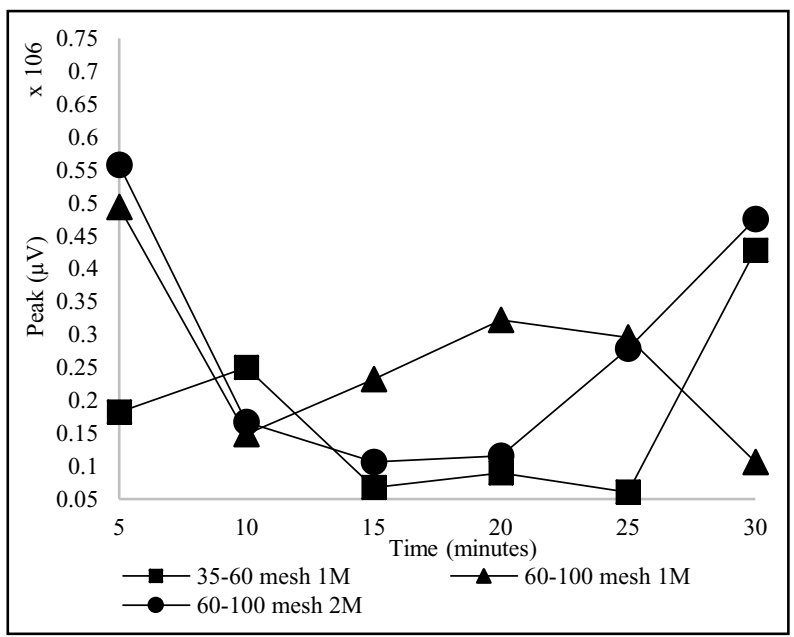

Figure 1. Time vs Peak for Pre-treated ZAL

The GC analysis was also done to impregnated $\mathrm{Ag}_{\mathrm{x}} \mathrm{O}$ /ZAL, and can be seen on Figure 2. The figures showed graphs that compared the ZAL before and after impregnated by $\operatorname{Ag}_{\mathrm{x}} \mathrm{O}$. The $\mathrm{Ag}_{\mathrm{x}} \mathrm{O} / \mathrm{ZAL}$ that have the highest performance on adsorbing nitrogen is the $35-50$ mesh 1 mole/L. This may be caused by the low Ag impregnated within the zeolite sample, and also the high level of $\mathrm{Si} / \mathrm{Al}$ ratio. $\mathrm{Si} / \mathrm{Al}$ ratio have a significant effect on zeolite as explained before. The $\operatorname{Ag}_{\mathrm{x}} \mathrm{O} / \mathrm{ZAL}$ adsorbent shown a low performance to adsorb nitrogen, as the peak are higher rather than the not impregnated ZAL. This phenomenon not only shown on $\operatorname{Ag}_{\mathrm{x}} \mathrm{O}$ /ZAL $35-60$ mesh, but also with the $60-100$ mesh. The increased graph maybe caused by the impregnation of $\operatorname{Ag}_{\mathrm{x}} \mathrm{O}$, and it may plug the pores of ZAL that making it hard for nitrogen molecules to be adsorbed. Based on this, the impregnation process of $\operatorname{Ag}_{\mathrm{x}} \mathrm{O}$, decreased the performance of ZAL. The fluctuate graph in almost every end of the data was caused by the saturated condition on the adsorbent, which means that the adsorbent can no longer adsorb as much as nitrogen as before. As can be seen on Figure 4, the best adsorbent is ZAL 35 - 60 mesh $1 \mathrm{M}$. That was caused by its pore volume. The size of ZAL also corresponding to how better the adsorbent works. The smaller ZAL size has the biggest pore volume and also specific surface area, which helped the $\mathrm{Ag}_{\mathrm{x}} \mathrm{O}$ to stick to the pore volume and making it a better adsorbent.

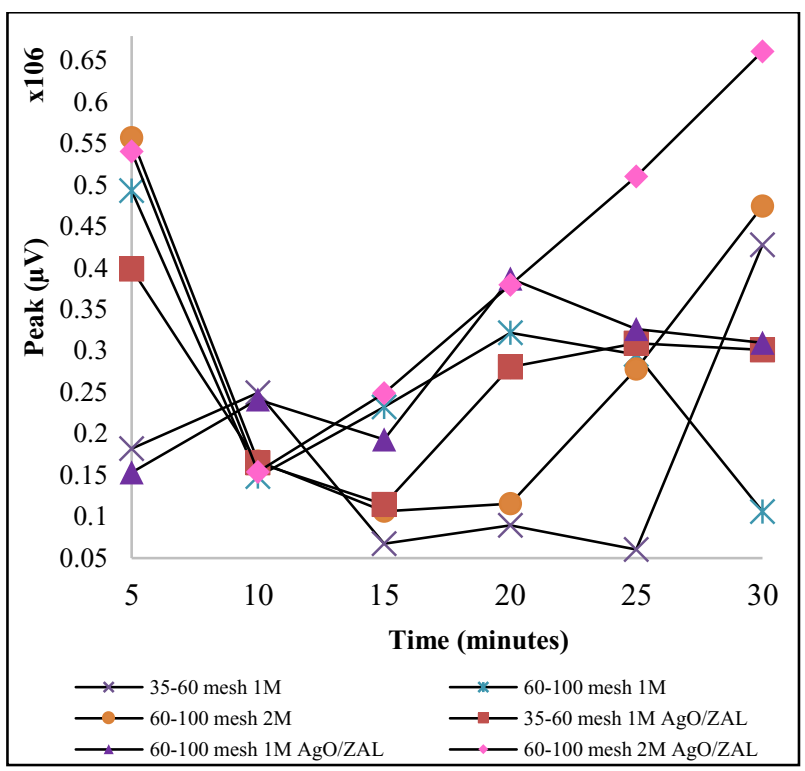

Figure 2. Time vs Peak for Impregnated and Un-impregnated ZAL

The explanation above also supported by the result of BET characterization on Table 7. As can be seen on Table 7, the pore diameter, pore volume and surface area of the impregnated $\mathrm{Ag}_{\mathrm{x}} \mathrm{O} / \mathrm{ZAL}$ decreased. This mainly caused by the impregnation process itself, in which the ZAL pores are plugged by the silver oxide and make it harder for nitrogen molecules to be adsorb within the pores or surfaces of the adsorbent.

Table 7. BET Characterization for Impregnated and Unimpregnated ZAL

\begin{tabular}{ccccc} 
& \multicolumn{2}{c}{$\begin{array}{c}35-60 \text { mesh 1 } \\
\text { mole/L }\end{array}$} & \multicolumn{2}{c}{$\begin{array}{c}60-100 \text { mesh } 2 \\
\text { mole/L }\end{array}$} \\
\cline { 2 - 5 } Parameter & Activate & Impreg. & Activate & Impreg. \\
\hline $\begin{array}{c}\text { Pore } \\
\text { diameter } \\
(\mathrm{nm})\end{array}$ & 11.047 & 10.952 & 11.138 & 11.019 \\
$\begin{array}{c}\text { Surface } \\
\text { area }\left(\mathrm{m}^{2} / \mathrm{g}\right) \\
\text { Pore }\end{array}$ & 62.849 & 60.455 & 64.373 & 55.412 \\
$\begin{array}{c}\text { volume } \\
\left(\mathrm{cm}^{3} / \mathrm{g}\right)\end{array}$ & 0.117 & 0.111 & 0.127 & 0.102 \\
\hline
\end{tabular}

The authors acknowledge Universitas Indonesia and PITTA program for the financial support. The authors also thankful to Badan Pengkajian dan Penerapan Teknologi (BPPT) on PUSPIPTEK, Serpong, Fakultas Matematika dan Ilmu Pengetahuan Alam (FMIPA) and Fakultas Teknik of Universitas Negeri Jakarta for the instruments to characterize the adsorbents.

\section{References}

1. Dianursanti, M. Delaamira, S. Bismo, Y. Muharam. Effect of Reaction Temperature on Biodiesel Production from Chlorella vulgaris using $\mathrm{CuO} /$ Zeolite as Heterogeneous Catalyst. 2nd International Conference on Tropical and Coastal Region Eco Development, Bali.(2016) 
2. Ertan, A., and Ozkan, F. $\mathrm{CO}_{2}$ and $\mathrm{N}_{2}$ Adsorption on the Acid ( $\mathrm{HCl}, \mathrm{HNO}_{3}, \mathrm{H}_{2} \mathrm{SO}_{4}$, and $\mathrm{H}_{3} \mathrm{PO}_{4}$ ) Treated Zeolite. Adsorption, 11, 151-156. (2005)

3. Haber, J., Derewinski, M., Dwigaji, S. \& Ritter, G. Proc Int. Symp. on Zeolite Catalyst, 1995: Acta Chim et hys, Szeged. \{1995)

4. Jacobs, P., Uytterhoeven, J. \& Beyer, H. Chem. Soc., s.l.: Faraday Trans. (1979)

5. Mara, A., Wijaya, K., Trisunaryati, W. \& Mudasir, M. Effect of Sulfuric Acid Treatment and Calcination on Natural Zeolites of Indonesia, Yogyakarta: Universitas Gajah Mada. (2016)

6. Scott, P. Oxygen - Pressure Swing Adsorption, US: IChem Ltd. (2000)

7. Slamet, Ellyana, M., Bismo, S. Modifikasi Zeolit Alam Lampung dengan Fotokatalis $\mathrm{TiO}_{2}$ melalui Metode Sol Gel dan Aplikasinya untuk Penyisihan Fenol. Jurnal Teknologi, 1, 59-68. (2008)

8. Syafii, F., Sugiarti, S. and Charlena. Modifikasi Zeolit Melalui Interaksi dengan $\mathrm{Fe}(\mathrm{OH})_{3}$ untuk Meningkatkan Kapasitas Tukar Anion, Bogor: Institut Pertanian Bogor. (2010) 